\title{
Regulation of pH in Rat Papillary Tubule Cells in Primary Culture
}

\author{
J. G. Kleinman, S. S. Blumenthal, J. H. Wiessner, K. L. Reetz, D. L. Lewand, N. S. Mandel, G. S. Mandel, \\ J. C. Garancis, and E. J. Cragoe, Jr. \\ Departments of Medicine and Pathology, The C. J. Zablocki Veterans Administration Medical Center, Milwaukee, Wisconsin 53295; \\ The Medical College of Wisconsin, Milwaukee, Wisconsin 53226; and Merck Sharp \& Dohme Research Laboratories, \\ West Point, Pennsylvania 19486
}

\begin{abstract}
To investigate the mechanisms responsible for urinary acidifcation in the terminal nephron, primary cultures of cells isolated from the renal papilla were grown as monolayers in a defined medium. Morphologically, cultured cells were epithelial in type, and similar to collecting duct principal cells. Cell pH measured fluorometrically in monolayers grown on glass slides showed recovery from acid loads in $\mathrm{Na}^{+}$-free media. Recovery was inhibited by cyanide, oligomycin $\mathbf{A}$, and $\boldsymbol{N}$-ethylmaleimide. Cyanide and oligomycin inhibited recovery less in the presence than in the absence of glucose. When cells were first acid loaded in a $\mathrm{Na}^{+}$-free medium and then exposed to external $\mathrm{Na}^{+}, \mathrm{pH}$ recovery also took place. This recovery exhibited first-order dependence on $\mathrm{Na}^{+}$concentration and was inhibited by 5 - $(\boldsymbol{N}$-ethyl- $\boldsymbol{N}$-isopropyl)amiloride. These studies demonstrate that in culture, collecting duct principal cells possess at least two mechanisms for acid extrusion: a proton ATPase and an $\mathrm{Na}^{+}-\mathrm{H}^{+}$exchanger. The former may be responsible for some component of the urinary acidification observed in the papillary collecting duct in vivo; the role of the latter in acidbase transport remains uncertain.
\end{abstract}

\section{Introduction}

$\mathrm{H}^{+}$secretion is attributed to a proton ATPase in mammalian distal nephron (1-3). This transport mechanism is thought to reside in a specific cell type, the intercalated cell (4), which is similar to the mitochondria-rich cell of the turtle bladder (5, 6). Although a membrane-bound ATPase has also been purified from whole bovine medulla (7), the cellular localization of this transport mechanism is uncertain. Intercalated cells have not been identified in the papillary collecting duct in rat, rabbit, or humans (4), yet acidification of the tubular fluid seems to occur within the papilla $(8-12)$.

The purpose of the current experiments was to examine the modes of $\mathrm{H}^{+}$secretion in cells isolated from rat renal papilla and grown in primary culture. The results of these studies demonstrate the presence of two $\mathrm{H}^{+}$transport systems, one

Portions of this work were presented at the Annual Meeting of the American Federation for Clinical Research, Washington, D.C., 2-5 May, 1986, and were published in abstract form (1986. Clin. Res. 34:601A).

Address correspondence to Dr. Kleinman, Renal Disease Section/ $111 \mathrm{~K}$, C. J. Zablocki Veterans Administration Medical Center, 5000 W. National Ave., Milwaukee, WI 53295.

Received for publication 17 July 1986 and in revised form 8 July 1987.

The Journal of Clinical Investigation, Inc.

Volume 80, December 1987, 1660-1669 having characteristics consistent with an $\mathrm{H}^{+}$-ATPase and one having characteristics of an $\mathrm{Na}^{+}-\mathrm{H}^{+}$exchanger.

\section{Methods}

Papillary collecting duct cells were isolated using a modification of methods reported by Grenier, Rollins, and Smith (13). Kidneys were harvested from 150-250-g Sprague-Dawley rats and papillae were dissected at their junctions with the medullary rays. The tissue was minced and suspended in $10 \mathrm{ml}$ of Kreb's-Ringer phosphate buffer, $\mathrm{pH}$ 7.3 , containing $2 \mathrm{mg} / \mathrm{ml}$ collagenase (CLS II; Worthington Biochemical Corp., Freehold, NJ). This mixture was incubated for $2 \mathrm{~h}$ at $37^{\circ} \mathrm{C}$, gassed with $5 \% \mathrm{CO}_{2} / 95 \% \mathrm{O}_{2}$, and periodically agitated by aspiration into a 10-ml pipette. When the tissue was well dispersed, 2 vol of distilled water were added and the suspension allowed to stand for 5 $\mathrm{min}$. The cells were then pelleted by centrifugation at $500 \mathrm{~g}$ for $5 \mathrm{~min}$ and washed twice in Kreb's-Ringer phosphate buffer. The cells were then suspended in $10 \mathrm{ml}$ of a 1:1 mixture of Ham's F-12 and Dulbecco's modified Eagle's media, containing $10 \%$ fetal calf serum, penicillin-streptomycin (1:100), and $10 \mathrm{mM}$ Hepes. Five-million cells were then plated in $2 \mathrm{ml}$ of the same medium in $35-\mathrm{mm}$ plastic culture dishes (Costar, Cambridge, MA) containing a $9 \times 18$-mm glass coverslip. The cultures were maintained at $37^{\circ} \mathrm{C}$ and gassed with $5 \%$ $\mathrm{CO}_{2} / 95 \% \mathrm{O}_{2}$ in a humidified incubator. After $24 \mathrm{~h}$ of incubation, the medium was changed to one that was serum free and contained 5 $\mu \mathrm{g} / \mathrm{ml}$ transferrin, $5 \mu \mathrm{g} / \mathrm{ml}$ insulin, $50 \mathrm{nM}$ hydrocortisone, $10 \mathrm{nM}$ sodium selenite, and $5 \mathrm{pM}$ triiodothyronine. Thereafter the medium was changed every $48 \mathrm{~h}$. Cell fluorescence experiments were performed when the cells had achieved $70-90 \%$ confluence on the coverslips.

$\mathrm{H}^{+}$transport was assessed by observing changes in the fluorescence of intracellular 2,7-biscarboxyethyl-5(6)-carboxyfluorescein (BCECF). ${ }^{1}$ The acetoxymethyl ester of this probe (BCECF-AM) was added to culture dishes in a final concentration of $10 \mu \mathrm{M}$ and the cells incubated with it for $1 \mathrm{~h}$. Thereafter the coverslips were removed from the dishes and washed with the buffer to be used for the various protocols. In addition to the salts specified in these protocols (see Results), this buffer always included $5 \mathrm{mM} \mathrm{KCl}, 2.5 \mathrm{mM} \mathrm{CaCl}_{2}, 1 \mathrm{mM} \mathrm{MgSO}_{4}$, and $15 \mathrm{mM}$ Hepes titrated with Tris base to the desired pH. $5.5 \mathrm{mM}$ D-glucose was present except in the glucose-free buffers where it was replaced with mannitol. Each coverslip was then mounted in a holder constructed to maintain it within an acrylic cuvette at an angle of $68^{\circ}$ to the incident light beam. Fluorescence intensity was monitored at $30^{\circ} \mathrm{C}$ in a Perkin-Elmer LS-5 fluorescence spectrophotometer at two excitation wavelengths, 450 and $504 \mathrm{~nm}$, and at one emission wavelength, $550 \mathrm{~nm}$.

Calibrations of cell $\mathrm{pH}$ were performed by exposing monolayers to $140 \mathrm{mM} \mathrm{KCl}$ buffered with Tris-Hepes at various $\mathrm{pH}$ values, adding 1 $\mu \mathrm{g} / \mathrm{ml}$ nigericin, and observing the fluorescence ratios of the readings at 504- and 450-nm excitation wavelengths. The resulting calibration curves typically had $r$ values $>0.99$ and did not differ significantly among monolayers from the same culture group obtained on the same day. Thus, a single calibration was performed daily to calculate apparent cell $\mathrm{pH}$ values observed during the experimental maneuvers.

1. Abbreviations used in this paper: BCECF, 2,7-biscarboxyethyl-5(6)carboxyfluorescein; BCECF-AM, acetoxymethyl BCECF. 
After each change of solution in the cuvette, the $\mathrm{pH}$-independent fluorescence at $450 \mathrm{~nm}$ excitation was adjusted to a value of 20 to compensate for loss of dye from cells or loss of cells from the coverslip. Tracings were not accepted if this value changed by $>5 \%$ during recording of a pH transient. The tracings shown depict the results of representative experiments. Each maneuver was performed three times or more in at least two different cell culture groups (Tables I and II).

Quantification of the rate of $\mathrm{Na}^{+}$-dependent $\mathrm{pH}$ recovery was assessed by determining the slope of the initial $\mathrm{pH}$ change after addition of $\mathrm{Na}^{+}$. The $S / V$ versus $S$ relationship, where $S=\left[\mathrm{Na}^{+}\right]$in millimolars and $\mathrm{V}=$ rate of $\mathrm{pH}$ recovery in units per minute; was calculated and apparent $K_{\mathrm{m}}$ and $V_{\max }$ value was derived to produce the result for an individual monolayer.

BCECF-AM was obtained from Molecular Probes, Inc., Eugene, OR. Oligomycin, $N$-ethylmaleimide, and nigericin were obtained from Sigma Chemical Co., St. Louis, MO. The 5-( $N$-ethyl- $N$-isopropyl)amiloride was synthesized by a previously described procedure (14). Before use BCECF-AM and 5-( $N$-ethyl- $N$-isopropyl)amiloride were dissolved in dimethyl sulfoxide, oligomycin and nigericin were dissolved in ethanol, and $N$-ethylmaleimide was dissolved in water. Stock solution additions were always $<1 \%$ of the volume of the solutions in the cuvette, and vehicles alone at this volume were without effects on cell $\mathrm{pH}$.

For electron microscopy, cell monolayers were grown on plastic coverslips and fixed in Karnovsky's solution. For transmission electron microscopy, they were postfixed in $1 \%$ osmium tetroxide and then embedded in Spur's low viscosity resin. Thin sections were stained with lead citrate and uranyl acetate and then examined with an EMU-4B electron microscope (RCA Corp., Lancaster, PA) operated at $50 \mathrm{kV}$. For scanning electron microscopy, fixed specimens underwent critical point drying with $\mathrm{CO}_{2}$. They were then mounted on carbon planchets and carbon coated in a vacuum chamber (Denton Vacuum Inc., Cherry Hill, NJ). The monolayers were then examined with a scanning electron microscope (model 1200; Advanced Metals Research Corp., Bedford, MA).

Succinic dehydrogenase staining was performed on formalin-fixed monolayers grown on glass slides by the method of Pearse (15).

\section{Results}

Morphology of papillary cells in culture. Fig. 1 is a phase-contrast micrograph of papillary cells grown in primary culture. They demonstrate a homogeneous polygonal shape and are $\sim 13 \mu \mathrm{m}$ in diameter. Evidence of vectorial fluid transport is present in the form of cell blisters or hemicysts. Representative cultures examined by transmission electron microscopy did not show evidence of fibroblast contamination. A homogeneous epithelial cell type was revealed (Fig. 2) that demonstrated apical microvilli, intercellular junctions, basolaterally located nuclei, basolateral cell infoldings, and a small number of mitochondria. Fig. 3 is a scanning electron micrograph of the cultured cells that shows the apical surfaces covered with short microvilli and long, single, centrally placed cilia. This morphology is characteristic of collecting duct principal cells (4). Further evidence that the cultured cells are principal cells rather than intercalated cells is provided by the failure to demonstrate positive succinic dehydrogenase staining (Fig. 4) (16).

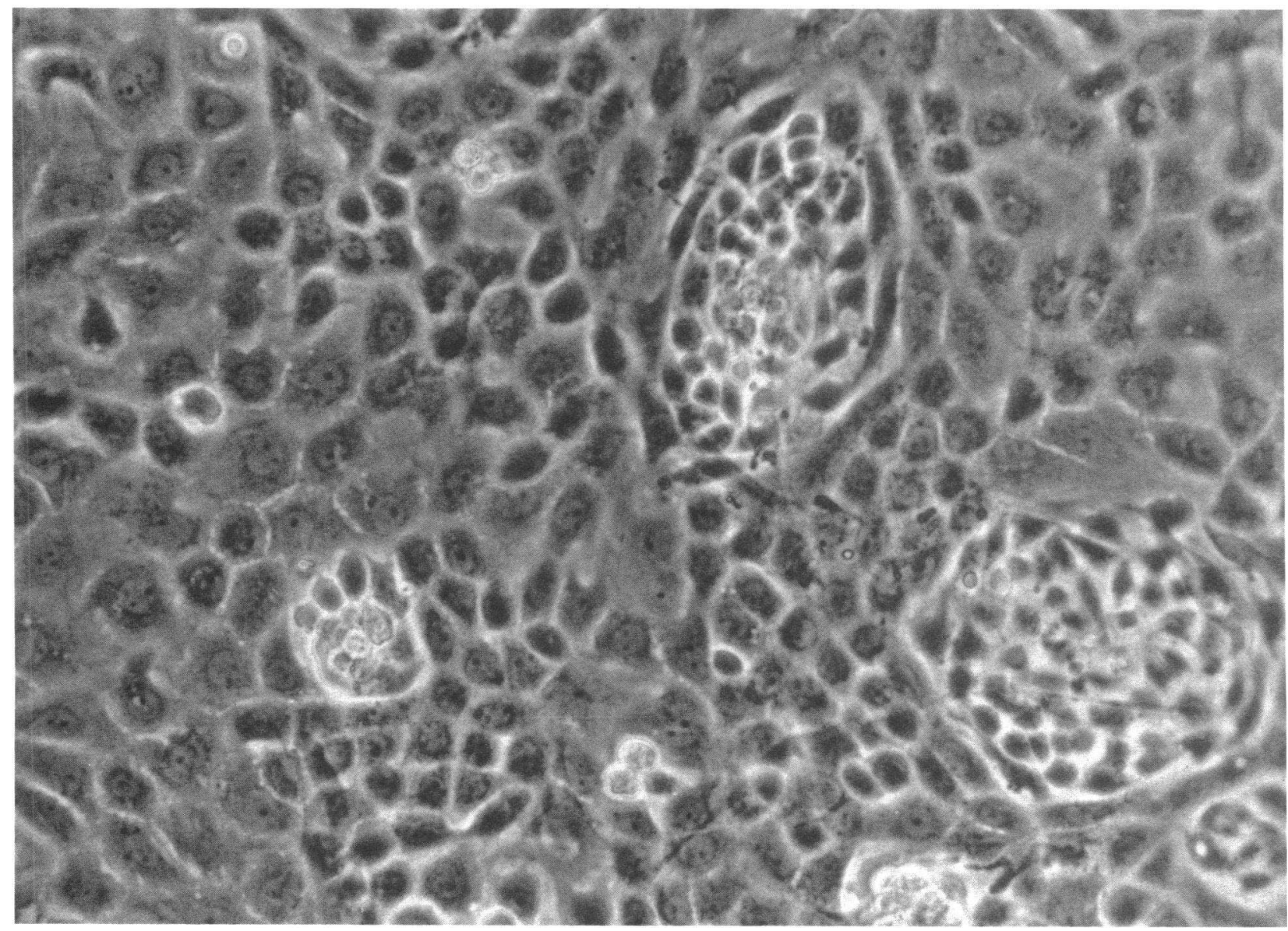

Figure 1. Phase-contrast photomicrograph of rat renal papillary cells in primary culture. $\times 320$. 


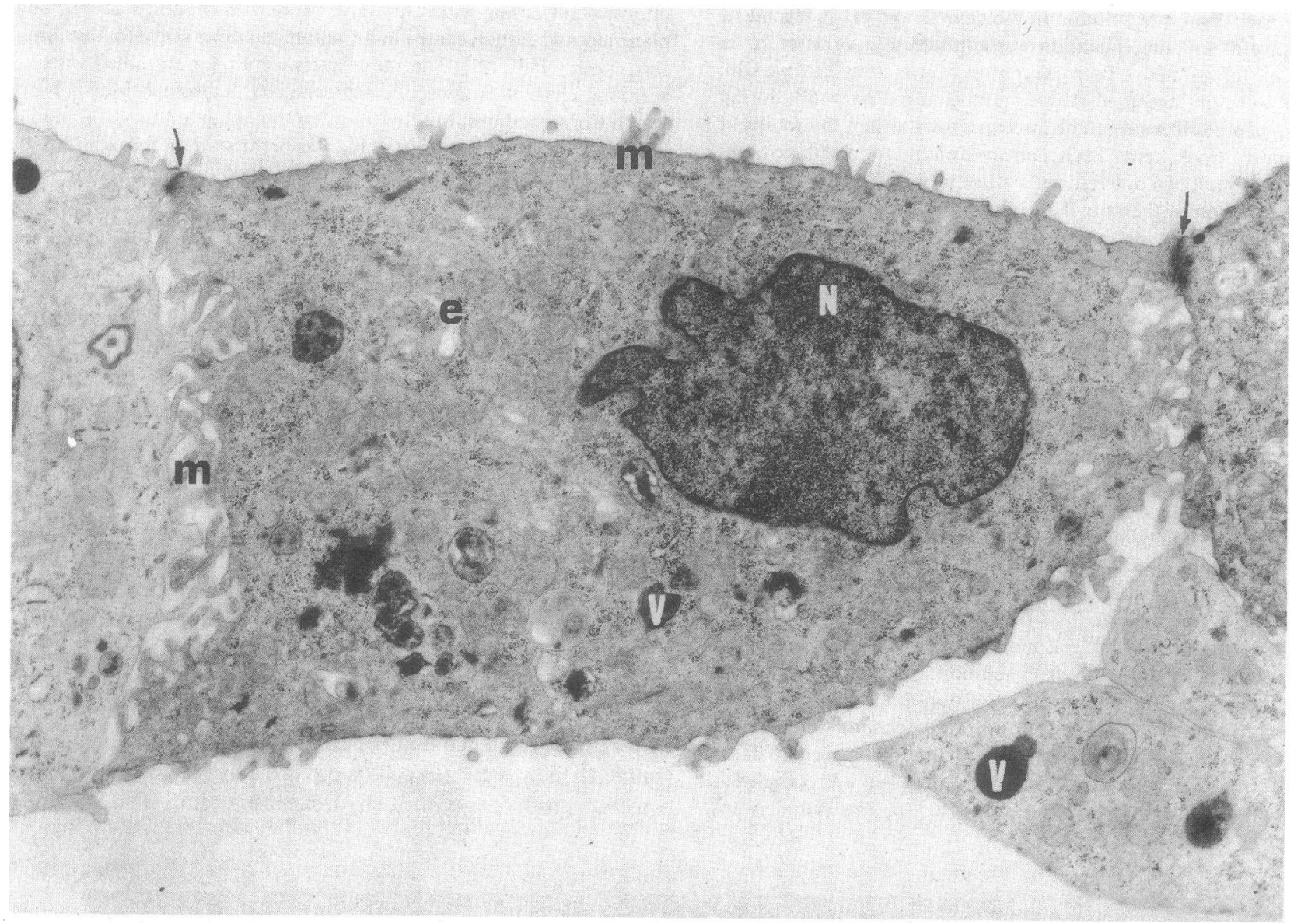

Figure 2. Transmission electronmicrograph of renal papillary cells in primary culture. Microvilli $(m)$; nucleus $(N)$; endoplasmic reticulum $(e)$; autophagic vacuoles $(V)$; and cellular junctions (arrows). $\times 12,800$.

$\mathrm{Na}^{+}$-independent $\mathrm{pH}$ regulation. The monolayers were loaded with acid by two protocols: $(i)$ exposure to and removal from $\mathrm{NH}_{4} \mathrm{Cl}$, and (ii) exposure to propionate. The initial BCECF cell fluorescence in both protocols was determined in an extracellular medium containing $135 \mathrm{mM} \mathrm{NaCl}$, buffered with $15 \mathrm{mM}$ Hepes-Tris at $\mathrm{pH}$ 7.3. The left tracing of Fig. $5 \mathrm{~A}$ shows the change in cell $\mathrm{pH}$ that occurred when the original buffer was replaced with one containing $115 \mathrm{mM}$ choline $\mathrm{Cl}$ and $20 \mathrm{mM} \mathrm{NH}_{4} \mathrm{Cl}$. Cell $\mathrm{pH}$ rose abruptly, presumably due to the rapid entry of $\mathrm{NH}_{3}$. When the $\mathrm{NH}_{4}^{+}$-containing buffer was changed to one containing choline alone, cell $\mathrm{pH}$ then decreased to a value below baseline because of the rapid loss of $\mathrm{NH}_{3}$ and retention of the relatively impermeant $\mathrm{NH}_{4}^{+}$. After this maneuver, cell $\mathrm{pH}$ increased towards baseline. The leftmost tracing of Fig. $5 \mathrm{~B}$ shows the result of replacing the initial $\mathrm{Na}^{+}$-containing buffer with one containing $115 \mathrm{mM}$ choline $\mathrm{Cl}$ and $20 \mathrm{mM}$ propionate. Cell $\mathrm{pH}$ fell abruptly, presumably due to the entry of the relatively permeant propionic acid, and then recovered towards baseline.

Effect of metabolic inhibitors on $\mathrm{Na}^{+}$-independent $\mathrm{pH}$ regulation. The right tracings of Fig. 5 show the effect of $\mathrm{CN}^{-}$on $\mathrm{Na}^{+}$-independent $\mathrm{pH}$ regulation. Incubation in a $\mathrm{Na}^{+}$-containing, glucose-free buffer with $2 \mathrm{mM} \mathrm{KCN}$ for $20 \mathrm{~min}$ prevented the recovery of cell $\mathrm{pH}$ from the imposed acid loads. This is consistent with a requirement for metabolic energy of cell $\mathrm{pH}$ regulation (17). Since medullary and papillary tissue appear to have a high capacity for glycolysis (18), we examined whether $\mathrm{pH}$ recovery in the absence of $\mathrm{Na}^{+}$could be sustained by glucose alone. Fig. 6 shows studies utilizing the same protocols as in Fig. 5. As can be seen, considerable capacity for $\mathrm{pH}$ recovery was retained by the cells after incubation with $\mathrm{KCN}$ in the presence of $5.5 \mathrm{mM}$ glucose.

The results of these experiments are summarized in the topmost sections of Table I $\left(\mathrm{NH}_{4}^{+}\right.$loading) and Table II (propionate loading). Cyanide significantly inhibited $\mathrm{pH}$ recovery in both glucose-containing and glucose-free buffers. However, despite similar falls in $\mathrm{pH}$ after acid loading $(\Delta \mathrm{pH})$ and starting $\mathrm{pH}$ values ( $\mathrm{pH}$ nadir), the slopes of $\mathrm{pH}$ recovery were significantly greater after $\mathrm{KCN}$ exposure in glucose-containing solutions compared with $\mathrm{KCN}$ exposure in glucose-free solutions.

Oligomycin, an inhibitor of the mitochondrial $\mathrm{H}^{+}$-ATPase, prevents oxidative ATP generation (19). In the next series of experiments, the effect of this inhibitor on the $\mathrm{Na}^{+}$-independent recovery of cell $\mathrm{pH}$ after acid loads was assessed. The left tracings of Fig. 7 indicate the control responses of the individual monolayers to the two acid-loading protocols. The right tracings show the results of the same acid-loading protocols after incubation of the monolayers in a glucose-free buffer with $5 \mu \mathrm{g} / \mathrm{ml}$ oligomycin. This treatment also abolished cell $\mathrm{pH}$ recovery.

In a manner similar to the cyanide experiments, monolayers exposed to oligomycin in a glucose-containing buffer 


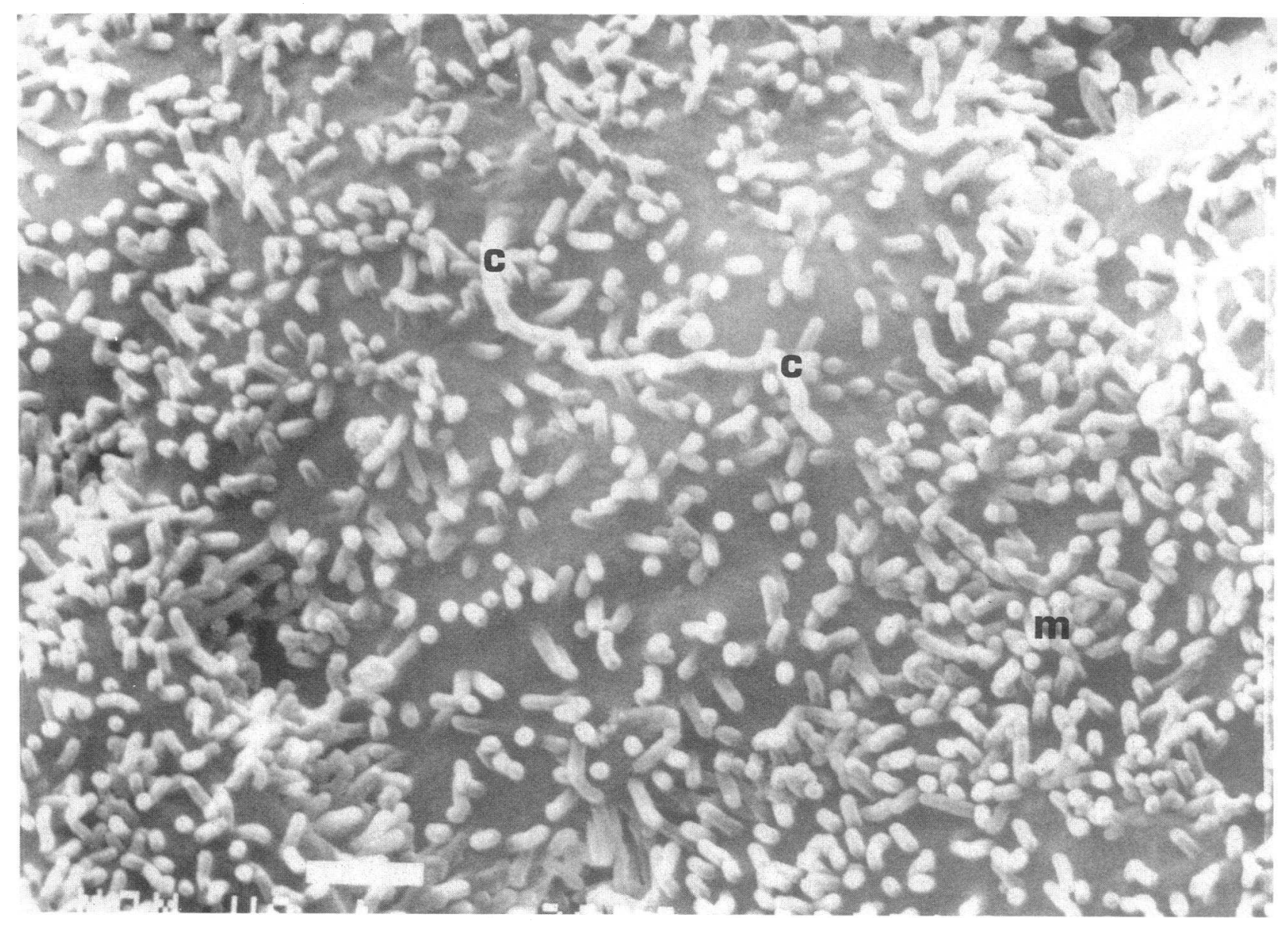

Figure 3. Scanning electron photomicrograph of renal papillary cells in culture. Short microvilli $(m)$; and central cilium $(c) . \times 15,000$.

maintained a greater rate of $\mathrm{pH}$ recovery after acid loading than monolayers exposed to the inhibitor in glucose-free buffer. These results are summarized in the middles sections of Table I ( $\mathrm{NH}_{4}^{+}$loading) and Table II (propionate loading). In glucose-containing solutions, oligomycin did not significantly inhibit $\mathrm{pH}$ recovery after $\mathrm{NH}_{4}^{+}$loading, but did significantly inhibit $\mathrm{pH}$ recovery after propionate. In the absence of glucose, however, the $\mathrm{pH}$ recovery rates after oligomycin exposure were significantly less than in glucose-containing buffer. These results confirm the requirement for metabolic energy of $\mathrm{pH}$ recovery under these experimental conditions.

Effect of a plasma membrane $\mathrm{H}^{+}$-ATPase inhibitor on $\mathrm{Na}^{+}$-independent $\mathrm{pH}$ regulation. $\mathrm{N}$-ethylmaleimide inhibits proton transport and $\mathrm{H}^{+}$-ATPase activity in a number of epithelia $(7,17,20)$. The effect of this agent on cell $\mathrm{pH}$ regulation was examined in the next series of studies. The left tracings of Fig. 8 indicate the control responses of the individual monolayers to the two acid-loading protocols. The right tracings show the results of the same protocols after incubation of the monolayers in a buffer containing $10 \mu \mathrm{M} \mathrm{N}$-ethylmaleimide for $20 \mathrm{~min}$. As shown, this agent also abolished $\mathrm{Na}^{+}$-independent $\mathrm{pH}$ recovery from acid loads.

The results of the experiments with $\mathrm{N}$-ethylmaleimide are summarized in the lowest sections of Table $\mathrm{I}\left(\mathrm{NH}_{4}^{+}\right.$loading) and Table II (propionate loading). As can be seen, despite equivalent or greater $\Delta \mathrm{pH}$ values and similar or lower $\mathrm{pH}$ nadir values, $N$-ethylmaleimide exposure (in the presence of glucose) abolished $\mathrm{pH}$ recovery. These results suggest that $\mathrm{Na}^{+}$-independent $\mathrm{pH}$ recovery is due to the action of an $\mathrm{H}^{+}$ATPase.

Effect of $\mathrm{Na}^{+}$on $\mathrm{pH}$ recovery. The effect of $\mathrm{Na}^{+}$on cell $\mathrm{pH}$ recovery was investigated by incubating monolayers in a solution containing $140 \mathrm{mM}$ choline $\mathrm{Cl}$ and buffered with HepesTris at $\mathrm{pH}$ 7.1. $\mathrm{H}^{+}$loading was accomplished by adding 1 $\mu \mathrm{g} / \mathrm{ml}$ nigericin, allowing cell $\mathrm{pH}$ to stabilize, and adding 10 $\mathrm{mg} / \mathrm{ml}$ albumin to terminate the effect of the nigericin. Then small volumes of a $22.5 \% \mathrm{NaCl}$ solution were added to achieve various $\mathrm{Na}^{+}$concentrations ranging from 3 to $60 \mathrm{mM}$. Only a very slow $\mathrm{pH}$ recovery (below $0.01 \mathrm{pH} \mathrm{U} / \mathrm{min}$ ) was observed without added $\mathrm{Na}^{+}$using this protocol; this was neglected in calculating rates of $\mathrm{Na}^{+}$-dependent $\mathrm{pH}$ recovery. Addition of equivalent moles of a choline $\mathrm{Cl}$ solution also did not affect cell $\mathrm{pH}$ recovery. Initial rates of recovery in response to $\mathrm{NaCl}$ were used to generate a Hanes-Woolf relationship. The composite graph is shown in Fig. 9. Table III reports $K_{\mathrm{m}}$ and $V_{\max }$ values from 13 individual monolayers from five culture groups, each with an $r$ value for the Hanes-Woolf plots $>0.9$. Kinetic values were comparable by either method.

The effect of the amiloride-analogue 5-( $N$-ethyl- $N$-isopropyl)amiloride on $\mathrm{Na}^{+}$-dependent $\mathrm{pH}$ recovery was investigated by exposing monolayers acid loaded with nigericin in $\mathrm{Na}^{+}$-free media to different concentrations of 5-( $N$-ethyl- $N$-isopropyl) amiloride or to vehicle alone followed by $50 \mathrm{mM} \mathrm{NaCl}$. The initial rates of $\mathrm{pH}$ recovery per minute were used to generate a 

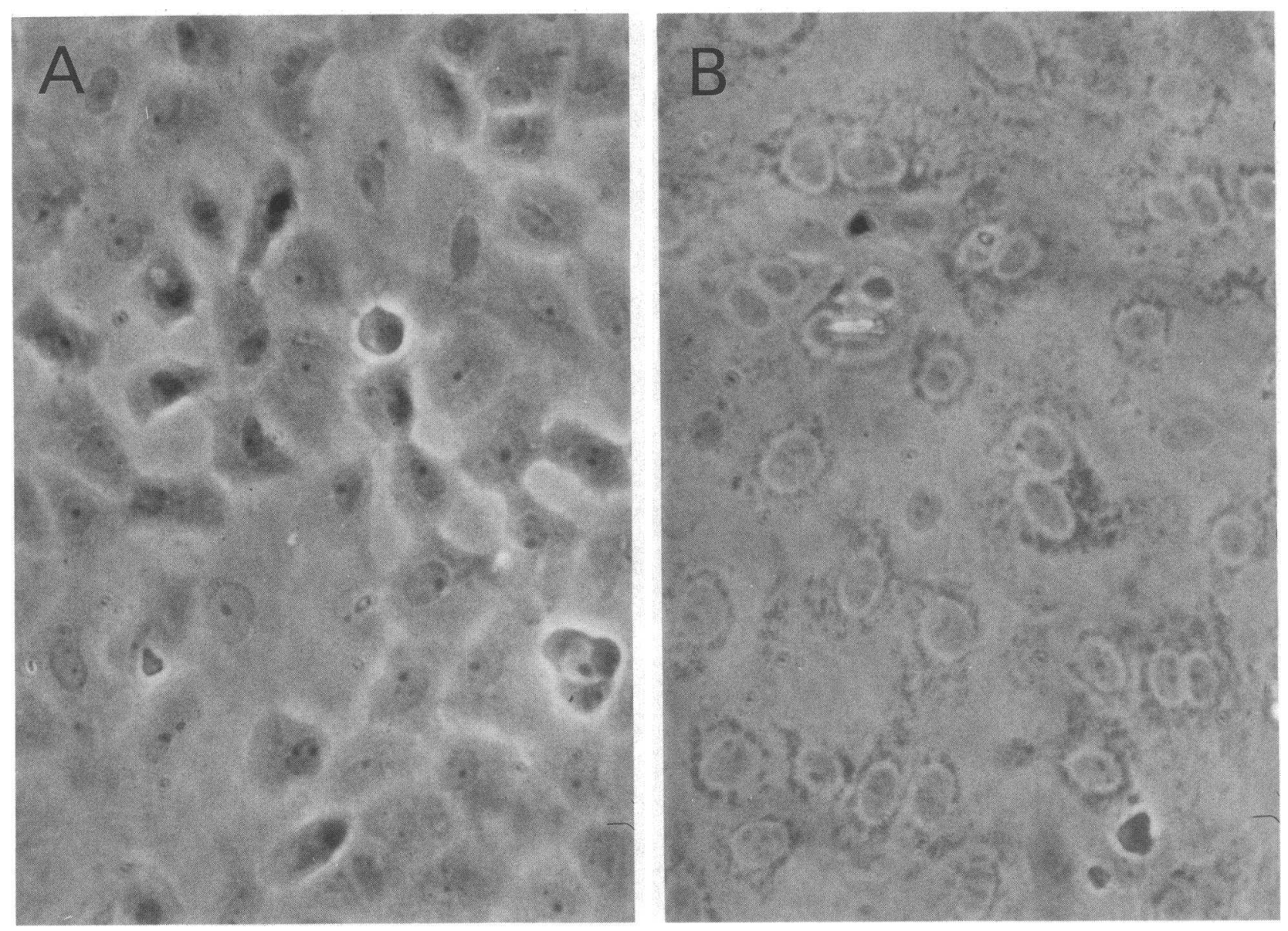

Figure 4. Succinic dehydrogenase staining of renal papillary cells in primary culture $(A)$, and for comparison mouse proximal tubule cells in primary culture $(B)$. Phase-contrast photomicrograph. $\times 384$.

Dixon plot, as shown in Fig. 10. The inhibition constant $\left(K_{\mathrm{i}}\right)$ value derived from this relationship was $0.8 \mu \mathrm{M}$.

\section{Discussion}

Cytoplasmic $\mathrm{pH}$ regulation is a characteristic of most living cells, which possess, several systems capable of transporting acid or base equivalents across the plasma membrane (21). These include cation- $\mathrm{H}^{+}$and anion- $\mathrm{HCO}_{3}^{-}\left(\right.$or $\mathrm{OH}^{-}$) exchangers, anion- $\mathrm{H}^{+}$and cation- $\mathrm{HCO}_{3}^{-}$(or $\mathrm{OH}^{-}$) symporters, and electrogenic $\mathrm{H}^{+}$and $\mathrm{HCO}_{3}^{-}$transporters. These systems have been characterized as simple diffusive mechanisms or facilitated (carrier mediated) transport, and have been shown to be passive, secondarily active, or directly coupled to supplies of metabolic energy. The $\mathrm{pH}$ regulating systems of renal tubule cells are also involved in the transepithelial movement of acid or base equivalents and, thus, urinary acidification.

BCECF has many characteristics that make it an ideal probe for intracellular $\mathrm{pH}(22,23)$. BCECF-AM is lipophylic and rapidly enters the cell, where it is converted to the fluorescent BCECF by intracellular esterases. BCECF has a $\mathrm{pK}_{\mathrm{a}}$ of $\sim 7.2$, which makes it a sensitive probe for cytoplasmic $\mathrm{pH}$ in the physiologic range. It is confined to the cytoplasmic cellular compartment and has a sufficiently stable isosbestic point to permit correction for any leakage that may occur. Titration of solutions of BCECF have verified the fact that the fluorescence response of the dye to $\mathrm{pH}$ changes in instantaneous (results not shown), thus confirming its suitability for determination of cell $\mathrm{pH}$ transients.

The question of whether metabolic processes causing the shift of acid or base equivalents to or from compartments within the cell not, accessible to BCECF could be responsible for the observed alterations in cell $\mathrm{pH}$ has not been examined in the current studies. Other investigators using maneuvers similar to those used in these studies to alter cell $\mathrm{pH}$ have demonstrated appropriate changes in proton extrusion as measured by titration of extracellular medium or extracellular $\mathrm{pH}$ changes $(17,24)$.

The cultured cells used in these studies are derived from the white papilla. The original cell suspension, therefore, should contain inner medullary collecting duct segments designated $\mathrm{IMCD}_{2}$ and $\mathrm{IMCD}_{3}(4)$ as well as loop of Henle thin limb cells, interstitial cells, and uroepithelial cells that line the renal pelvis. The efficacy of hypotonic lysis for removing these contaminants has not been verified. However, the cells as grown do not demonstrate morphology consistent with origin from the latter cell types. The preponderance of the cells are, in fact, epithelial in type. This is apparent from the intercellular junctions observed in transmission electron micrographs (25). It is clear, however, that these structures do not restrict access of peptide hormones to the apical membrane (13). Thus it is unlikely that the effects of maneuvers used in the current stud- 
A

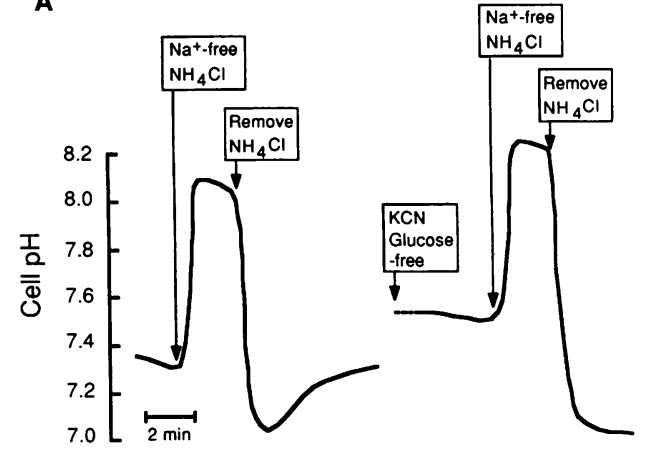

B

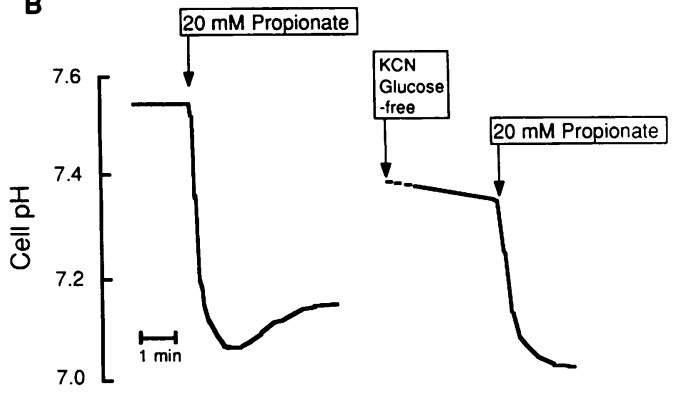

Figure 5. Effect of $\mathrm{CN}^{-}$and glucose removal on $\mathrm{Na}^{+}$-independent $\mathrm{pH}$ recovery. BCECF-loaded monolayers were initially exposed to an extracellular medium containing $135 \mathrm{mM} \mathrm{NaCl}$ and $10 \mathrm{mM}$ HepesTris at $\mathrm{pH}$ 7.3. At the indicated points the cells were acid loaded in the absence of $\mathrm{Na}^{+}$by exposure to and removal from an $\mathrm{NH}_{4} \mathrm{Cl}$-containing medium $(A)$ or exposure to propionate $(B)$. In both panels the tracings show $\mathrm{pH}$ recovery from $\mathrm{Na}^{+}$-free acid loading before and after incubation of the monolayers for $20 \mathrm{~min}$ in a $\mathrm{Na}^{+}$-containing but glucose-free medium with $2 \mathrm{mM} \mathrm{KCN}$. Each panel depicts the results of a representative monolayer.

ies to alter acid-base transport are confined to the apical membrane and, thus, can serve to localize these $\mathrm{pH}$ regulating systems to this membrane.

In addition to the fact that intercalated cells have not been observed in rat papilla, the source of the cultures under study, no cells conforming to their morphology were observed in scanning electron micrographs. Because of its greater content of mitochondria compared with principal cells, intercalated cells have been identified by succinic dehydrogenase staining (16). Proximal tubule cells in primary culture show positive succinic dehydrogenase staining because of their large numbers of mitochondria, similar to intercalated cells. The cultures reported on here lack such staining. Finally, observation of BCECF-loaded cultures with fluorescence microscopy does not clearly indicate cellular $\mathrm{pH}$ heterogeneity as would be expected from the presence of subpopulations of cells transporting acid or base (26). From these considerations it appears likely that the $\mathrm{pH}$ regulatory systems observed in the current studies are a property of the rat papillary collecting duct principal cell in primary culture.

The proton translocating ATPase has been identified in turtle bladders, a turtle bladder epithelial cell line, and in rat and bovine renal medulla $(7,20,27,28)$. It has not, to our knowledge, been localized to a particular cell type within these tissues, nor have the studies cited above ruled out its presence in inner papillary tissue. The $\mathrm{Na}^{+}$-independent $\mathrm{pH}$ regulation
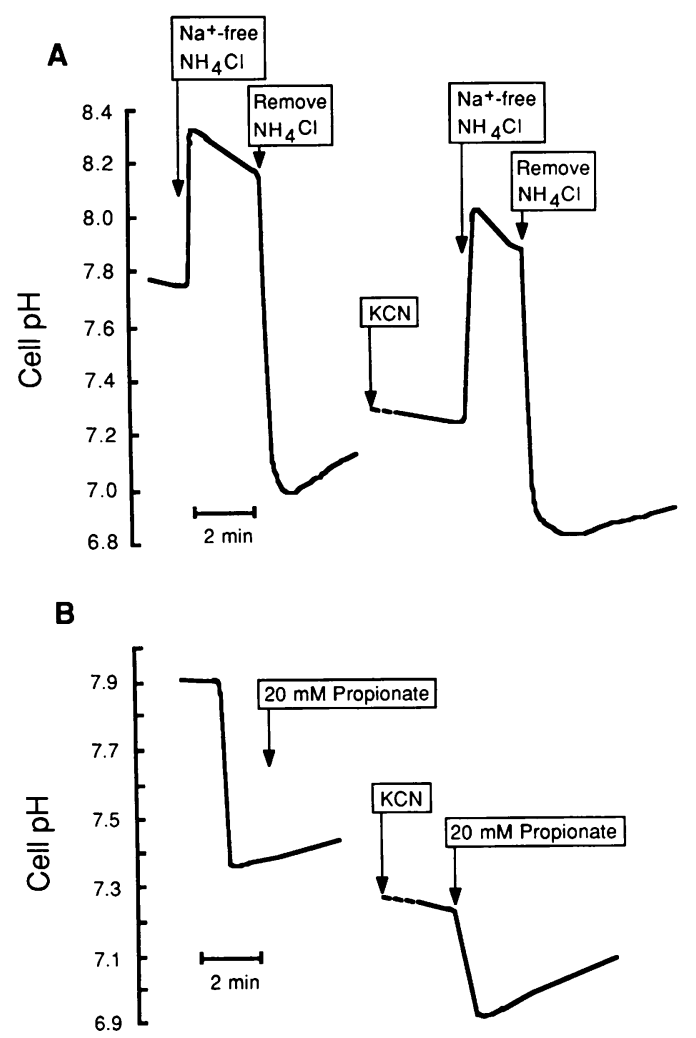

Figure 6. Effect of $\mathrm{CN}^{-}$on $\mathrm{Na}^{+}$-independent $\mathrm{pH}$ recovery in the presence of glucose. The experiments were performed in a identical manner to those shown in Fig. 4, except that all solutions contained $5.5 \mathrm{mM}$ glucose.

described in the present studies have characteristics suggesting that it may be a result of the action of an $\mathrm{H}^{+}$-ATPase. Interference with the supply of metabolic energy for transport by two different inhibitors of oxidative metabolism abolishes $\mathrm{Na}^{+}$-independent $\mathrm{pH}$ regulation. Provision of glucose in the presence of the oxidative metabolism inhibitors $\mathrm{CN}^{-}$and oligomycin preserved $\mathrm{Na}^{+}$-independent $\mathrm{pH}$ regulation to some degree. This is consistent with maintenance of the supply of ATP through the glycolytic capacity of cells in the renal papilla (18). Finally, the effect of exposure of the cells to $N$-ethylmaleimide in the presence of glucose provides further support for the idea that this form of $\mathrm{pH}$ regulation is due to the $\mathrm{H}^{+}$-ATPase. This inhibitor has been shown to be specific for $\mathrm{H}^{+}$-ATPases derived from bovine renal medulla (including papilla?), endocytotic vesicles, Golgi complex, and microsomes of various morphologies $(7,28-32)$. These experiments, then, support the notion that rat papillary duct principal cells possess an $\mathrm{H}^{+}$ATPase.

Distal nephron acidification has not generally been thought to depend on $\mathrm{Na}^{+}$. In turtle urinary bladder, a distal nephron model, electrogenic proton secretion is not critically dependent on $\mathrm{Na}^{+}$transport (33). $\mathrm{Na}^{+}$absorption may provide a favorable electrical profile for the $\mathrm{H}^{+}$pump across the luminal membrane $(34,35)$, but electrically silent $\mathrm{Na}^{+}-\mathrm{H}^{+}$exchange has not been demonstrated in this tissue. Similar $\mathrm{H}^{+}$ transport characteristics have been demonstrated in mammalian cortical collecting duct, again without apical $\mathrm{Na}^{+}-\mathrm{H}^{+}$exchange (36). Outer medullary collecting duct cell suspensions 
Table I. Cell pH Values and Transients in CPCD Cells Acid Loaded by Exposure to and Removal from $\mathrm{NH}_{4} \mathrm{Cl}$

\begin{tabular}{|c|c|c|c|c|c|}
\hline & Initial pH & $\mathrm{NH}_{4}^{+} \mathrm{pH}$ & pH nadir & $\Delta \mathrm{pH}$ & Slope \\
\hline & $U$ & $U$ & $U$ & $U$ & $U / \min$ \\
\hline Control & $7.81 \pm 0.06$ & $8.25 \pm 0.06$ & $7.25 \pm 0.07$ & $1.01 \pm 0.08$ & $0.08 \pm 0.02$ \\
\hline $\mathrm{KCN}+\mathrm{G}$ & $7.54 \pm 0.19$ & $8.17 \pm 0.12$ & $7.10 \pm 0.16$ & $1.08 \pm 0.06$ & $0.04 \pm 0.02$ \\
\hline $\mathrm{P}$ vs. $\mathrm{C}(n=6 / 2)$ & NS & NS & NS & NS & $<0.025$ \\
\hline Control & $7.36 \pm 0.10$ & $8.08 \pm 0.04$ & $6.86 \pm 0.10$ & $1.22 \pm 0.09$ & $0.04 \pm 0.00$ \\
\hline $\mathrm{KCN}-\mathrm{G}$ & $7.41 \pm 0.03$ & $7.97 \pm 0.03$ & $7.04 \pm 0.06$ & $0.93 \pm 0.05$ & $-0.02 \pm 0.01$ \\
\hline $\mathrm{P}$ vs. $\mathrm{C}(n=7 / 2)$ & NS & NS & NS & $<0.02$ & $<0.001$ \\
\hline P, C vs. C & $<0.005$ & $<0.05$ & $<0.02$ & NS & NS \\
\hline$P,+G$ vs. $-G$ & NS & NS & NS & NS & $<0.02$ \\
\hline Control & $7.46 \pm 0.08$ & $7.66 \pm 0.16$ & $7.27 \pm 0.10$ & $0.38 \pm 0.19$ & $0.02 \pm 0.01$ \\
\hline Oligo +G & $7.49 \pm 0.09$ & $7.56 \pm 0.09$ & $7.25 \pm 0.02$ & $0.30 \pm 0.11$ & $0.01 \pm 0.00$ \\
\hline $\mathrm{P}$ vs. $\mathrm{C}(n=3 / 2)$ & NS & NS & NS & NS & NS \\
\hline Control & $7.76 \pm 0.04$ & $8.14 \pm 0.05$ & $7.03 \pm 0.05$ & $1.11 \pm 0.06$ & $0.07 \pm 0.01$ \\
\hline Oligo -G & $7.48 \pm 0.05$ & $7.95 \pm 0.08$ & $7.19 \pm 0.06$ & $0.77 \pm 0.12$ & $-0.02 \pm 0.01$ \\
\hline P vs. $\mathrm{C}(n=8 / 3)$ & $<0.005$ & $<0.02$ & $<0.02$ & $<0.01$ & $<0.001$ \\
\hline P, C vs. C & $<0.01$ & $<0.005$ & $<0.05$ & $<0.001$ & $<0.025$ \\
\hline$P,+G$ vs. $-G$ & NS & $<0.02$ & NS & NS & $<0.05$ \\
\hline Control & $7.77 \pm 0.05$ & $8.10 \pm 0.04$ & $7.03 \pm 0.12$ & $1.07 \pm 0.07$ & $0.13 \pm 0.02$ \\
\hline $\mathrm{NEM}+\mathrm{G}$ & $7.57 \pm 0.08$ & $7.90 \pm 0.07$ & $6.62 \pm 0.09$ & $1.28 \pm 0.04$ & $-0.02 \pm 0.01$ \\
\hline P vs. $C(n=4 / 2)$ & $<0.05$ & $<0.01$ & $<0.002$ & $<0.05$ & $<0.005$ \\
\hline
\end{tabular}

Values are means \pm SEM; $n$, number of slides per number of platings. Controls are values from maneuvers performed before incubation of individual slides with inhibitors. The maneuvers were then repeated after 20 min incubation with the indicated inhibitors, $\mathrm{KCN}$, oligomycin(oligo), or $N$-ethylmaleimide (NEM) in the presence and absence of glucose $(+\mathrm{G}$ or $-\mathrm{G})$. Comparisons within groups, inhibitor versus control (P vs. $\mathrm{C}$ ), are by paired $t$ test; comparisons between groups, between controls (P, C vs. C), or between inhibitors with and without glucose (P, $+\mathrm{G}$ vs. $-\mathrm{G})$, are by unpaired $t$ test.

Table II. Cell pH Values and Transients in CPCD Cells Acid Loaded by Exposure to Propionate

\begin{tabular}{|c|c|c|c|c|}
\hline & Initial pH & pH nadir & $\Delta \mathrm{pH}$ & Slope \\
\hline & $U$ & $U$ & $U$ & $U / \min$ \\
\hline Control & $7.72 \pm 0.10$ & $7.37 \pm 0.02$ & $0.35 \pm 0.10$ & $0.02 \pm 0.01$ \\
\hline $\mathrm{KCN}+\mathrm{G}$ & $7.47 \pm 0.14$ & $7.20 \pm 0.11$ & $0.27 \pm 0.07$ & $0.02 \pm 0.01$ \\
\hline P vs. $\mathrm{C}(n=5 / 3)$ & NS & NS & NS & NS \\
\hline Control & $7.51 \pm 0.06$ & $7.13 \pm 0.08$ & $0.38 \pm 0.03$ & $0.04 \pm 0.01$ \\
\hline $\mathrm{KCN}-\mathrm{G}$ & $7.59 \pm 0.13$ & $7.25 \pm 0.08$ & $0.35 \pm 0.06$ & $-0.03 \pm 0.01$ \\
\hline$P$ vs. $C(n=4 / 3)$ & NS & NS & NS & $<0.05$ \\
\hline P, C vs. C & NS & $<0.02$ & NS & NS \\
\hline$P,+G$ vs. $-G$ & NS & NS & NS & $<0.002$ \\
\hline Control & $7.57 \pm 0.09$ & $7.28 \pm 0.05$ & $0.29 \pm 0.07$ & $0.04 \pm 0.00$ \\
\hline Oligo $+\mathbf{G}$ & $7.44 \pm 0.03$ & $7.13 \pm 0.06$ & $0.31 \pm 0.05$ & $0.01 \pm 0.00$ \\
\hline P vs. $\mathrm{C}(n=6 / 2)$ & NS & NS & NS & $<0.001$ \\
\hline Control & $7.71 \pm 0.02$ & $7.18 \pm 0.02$ & $0.53 \pm 0.03$ & $0.02 \pm 0.01$ \\
\hline Oligo -G & $7.50 \pm 0.03$ & $7.04 \pm 0.02$ & $0.46 \pm 0.02$ & $-0.02 \pm 0.00$ \\
\hline P vs. $C(n=5 / 2)$ & $<0.01$ & $<0.001$ & NS & $<0.005$ \\
\hline P, C vs. C & NS & NS & $<0.02$ & NS \\
\hline$P,+G$ vs. $-G$ & NS & NS & $<0.05$ & $<0.002$ \\
\hline Control & $7.72 \pm 0.04$ & $7.15 \pm 0.06$ & $0.57 \pm 0.05$ & $0.02 \pm 0.01$ \\
\hline $\mathrm{NEM}+\mathrm{G}$ & $7.48 \pm 0.06$ & $6.93 \pm 0.05$ & $0.55 \pm 0.03$ & $-0.03 \pm 0.00$ \\
\hline P vs. $C(n=4 / 2)$ & $<0.02$ & $<0.01$ & NS & $<0.01$ \\
\hline
\end{tabular}

Values are means $\pm \mathrm{SEM} ; n$, number of slides per number of platings. Controls are values from maneuvers performed before incubation of individual slides with inhibitors. The maneuvers were then repeated after $20 \mathrm{~min}$ incubation with the indicated inhibitors, $\mathrm{KCN}$, oligomycin(oligo), or $N$-ethylmaleimide (NEM) in the presence and absence of glucose (+G or $-\mathbf{G})$. Comparisons within groups, inhibitor versus control (P vs. $C$ ), are by paired $t$ test; comparisons between groups, between controls (P, C vs. C), or between inhibitors with and without glucose (P, +G vs. $-G)$, are by unpaired $t$ test. 

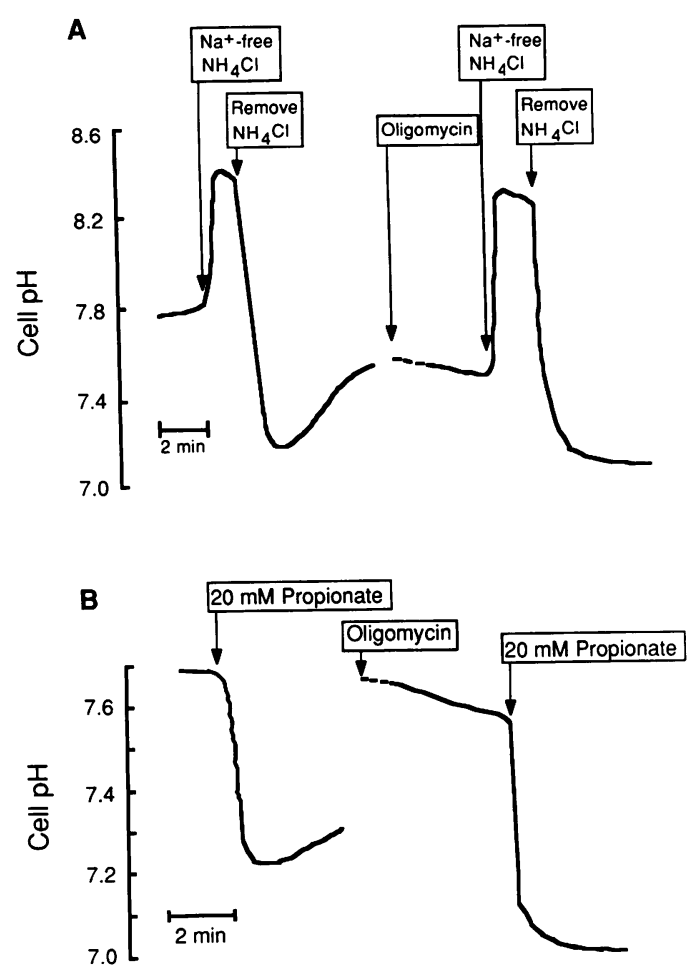

Figure 7. Effect of oligomycin on $\mathrm{Na}^{+}$-independent $\mathrm{pH}$ recovery. The experiments were performed identically to those preceding except that $\mathrm{Na}^{+}$-independent $\mathrm{pH}$ recovery was evaluated before and after incubation for $20 \mathrm{~min}$ with $5 \mu \mathrm{g} / \mathrm{ml}$ oligomycin in glucose-free buffer.

freshly isolated from rabbit kidneys also failed to demonstrate $\mathrm{Na}^{+}$dependence of $\mathrm{pH}$ regulation in studies performed utilizing techniques similar to those used in the current experiments (17). In contrast, La Belle has identified an amiloride-sensitive $\mathrm{Na}^{+}-\mathrm{H}^{+}$exchanger in vesicles from rabbit medullary tissue (presumably including papilla) (37). $\mathrm{Na}^{+}$kinetics are not avail-
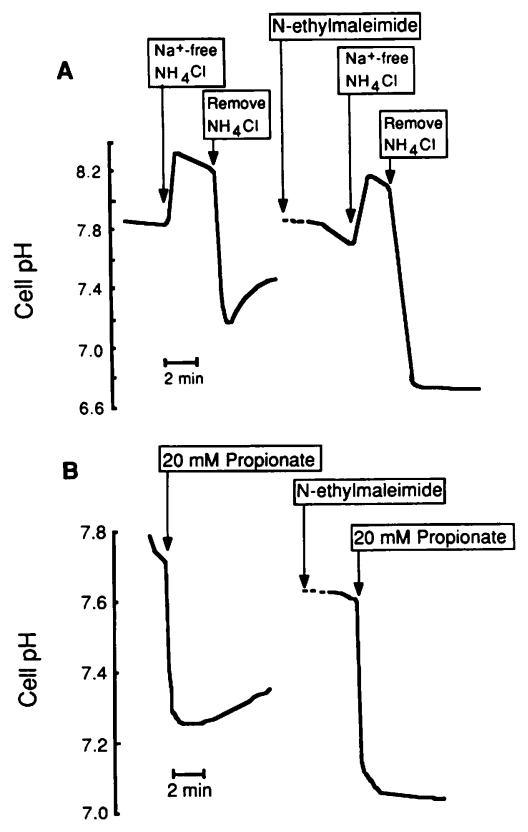

Figure 8. Effect of $N$ ethylmaleimide on $\mathrm{Na}^{+}$. independent $\mathrm{pH}$ recovery. The experiments were performed identically to those preceding except that $\mathrm{pH}$ recovery was evaluated before and after incubation of the cells for $20 \mathrm{~min}$ with $10 \mu \mathrm{M} N$-ethylmaleimide.

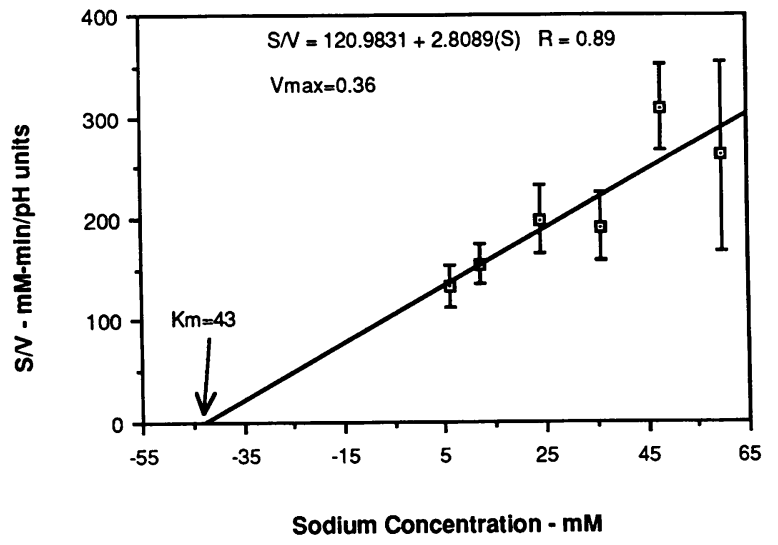

Figure 9. A composite Hanes-Woolf plot of $\mathrm{Na}^{+}$-dependent $\mathrm{pH}$ recovery following an acid load. BCECF-loaded monolayers of papillary cells were acid loaded in media containing $140 \mathrm{mM}$ choline $\mathrm{Cl}$ buffered with Hepes-Tris to $\mathrm{pH} 7.1$ and nigericin $(1 \mu \mathrm{g} / \mathrm{ml})$. Albumin was used to terminate the effect of the ionophore, and small quantities of a concentrated $\mathrm{NaCl}$ solution were added to generate different external $\mathrm{Na}^{+}$concentrations. Mean $\pm S E M$ of initial rates of $\mathrm{pH}$ change at each of six different $\mathrm{Na}^{+}$concentrations were used to construct the figure.

able for comparison, but the amiloride concentration at which $50 \%$ inhibition was observed $\left(K_{0.5}\right)$ was $60 \mu \mathrm{M}$. The current studies have revealed a $K_{\mathrm{i}}$ value of $0.8 \mu \mathrm{M}$ for 5 -( $(N$-ethyl- $N$ isopropyl)amiloride. This compound has been shown to be a 50 to 140 times more potent inhibitor for $\mathrm{Na}^{+}-\mathrm{H}^{+}$exchange systems in a variety of tissues $(38,39)$. An effect of 5 -( $N$-ethyl$N$-isopropyl)amiloride itself to dissipate cell-to-extracellular $\mathrm{pH}$ gradients was not observed in the current studies.

$\mathrm{Na}^{+}-\mathrm{H}^{+}$exchange has, of course, been demonstrated in renal cortical vesicles, proximal tubules (perfused, in suspension, or in primary culture), and in several cultured renal cell

Table III. Kinetic Values Derived from Hanes-Woolf Plots of Individual Slides

\begin{tabular}{lllrl}
\hline Exp. No. & $n$ & $r$ value & \multicolumn{1}{c}{$K_{\mathbf{m}}$} & $V_{\max }$ \\
\hline 1 & 3 & 0.997 & 9 & 0.13 \\
2 & 5 & 0.975 & 34 & 0.17 \\
3 & 4 & 0.905 & 62 & 0.22 \\
4 & 4 & 0.952 & 38 & 0.53 \\
5 & 4 & 0.938 & 27 & 0.38 \\
6 & 5 & 0.967 & 32 & 0.43 \\
7 & 8 & 0.918 & 115 & 1.52 \\
8 & 3 & 1.000 & 20 & 0.30 \\
9 & 4 & 0.979 & 34 & 0.43 \\
10 & 4 & 0.980 & 69 & 0.70 \\
11 & 4 & 0.950 & 43 & 0.38 \\
12 & 4 & 0.967 & 53 & 0.34 \\
13 & 4 & 0.961 & 65 & 0.38 \\
& & & $46 \pm 8$ & $0.45 \pm 0.10$ \\
& & Means \pm SEM & & \\
\hline
\end{tabular}

Values for $K_{\mathrm{m}}$ (millimolars) and $V_{\max }$ (pH units per minute) are derived from linear regressions of plots of $\left[\mathrm{Na}^{+}\right] / \mathrm{pH}$ change as a function of $\left[\mathrm{Na}^{+}\right]$for the indicated number of points $(n)$ in 13 individual slides of 5 different platings. 


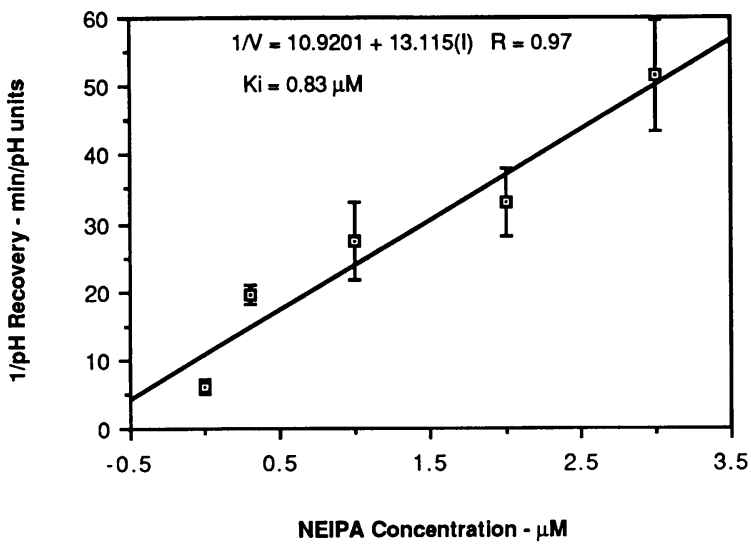

Figure 10. Dixon Plot of the effect of 5( $N$-ethyl- $N$-isopropyl)amiloride on $\mathrm{Na}^{+}$-dependent $\mathrm{pH}$ recovery. The cells were acid loaded as in Fig. 8. 5( $N$-ethyl- $N$-isopropyl)amiloride was added followed by $\mathrm{NaCl}$ to produce an external $\mathrm{Na}^{+}$concentration of $50 \mathrm{mM}$. Each point is the mean $\pm \mathrm{SEM}$ of initial rates of $\mathrm{pH}$ change of four to six individual monolayers.

lines (40-48). Due to differences in technique, $V_{\max }$ values for $\mathrm{pH}$ are not amenable to direct comparison; $K_{\mathrm{m}}$ values for $\mathrm{Na}^{+}$, however, are expressed in similar units, and appear to be between two and eight times higher in the primary papillary cultures than in other preparations. This value of $\sim 46 \mathrm{mM}$ is more than threefold higher than $K_{\mathrm{m}}$ values obtained in primary cultures of baby mouse proximal tubule cells by identical techniques (unpublished observations).

As indicated above, these studies cannot distinguish between apical and basolateral processes. It seems reasonable to consider that a papillary collecting duct $\mathrm{H}^{+}$-ATPase would be apically situated, as in other acid-secreting renal segments or uroepithelial tissue, in juxtaposition to the compartment being acidified $(8-11,33)$. It is quite possible, however, that the $\mathrm{Na}^{+}-\mathrm{H}^{+}$exchanger is present in the basolateral cell membrane where it serves to regulate cell $\mathrm{pH}$, as has been described in rabbit cortical collecting duct (49).

In summary, evidence for two modes of $\mathrm{pH}$ regulation in papillary tubule cells in primary culture have been presented. These systems are consistent with the presence of both an $\mathrm{H}^{+}$-ATPase and an $\mathrm{Na}^{+}-\mathrm{H}^{+}$exchanger. The existence of these systems may provide the cellular mechanisms in principal cells for internal $\mathrm{pH}$ regulation as well as the urinary acidification observed in the renal papilla.

\section{Acknowledgments}

This work was supported by The Veterans Administration and the National Kidney Foundation of Wisconsin.

\section{References}

1. Stone, D. K., D. W. Seldin, J. P. Kokko, and H. R. Jacobson. 1983. Anion dependence of rabbit medullary collecting duct acidification. J. Clin. Invest. 71:1505-1508.

2. Lombard, W. E., J. P. Kokko, and H. R. Jacobson. 1983. Bicarbonate transport in cortical and outer medullary collecting tubules. Am. J. Physiol. 244:F289-F296.

3. Stone, D. K., D. W. Seldin, J. P. Kokko, and H. R. Jacobson. 1983. Mineralocorticoid modulation of rabbit medullary collecting duct acidification. A sodium-independent effect. J. Clin. Invest. 72:2050-2059.

4. Madsen, K. M., and C. C. Tisher. 1986. Structural-functional relationships along the distal nephron. Am. J. Physiol. 250:F1-F15.

5. Scott, W. N., M. J. Yoder, and J. F. Gennaro, Jr. 1978. Isolation of highly enriched preparations of two types of mucosal cells of the turtle urinary bladder. Proc. Soc. Exp. Biol. Med. 158:565-571.

6. Rosen, S. 1970. Localization of carbonic anhydrase activity in turtle and toad urinary bladder mucosa. J. Histochem. Cytochem. 20:696-702.

7. Gluck, S., and Q. Al-Awqati. 1984. An electrogenic protontranslocating adenosine triphosphatase from bovine kidney medulla. J. Clin. Invest. 73:1704-1710.

8. Graber, M. L., H. H. Bengele, J. H. Schwartz, and E. A. Alexander. 1981. $\mathrm{pH}$ and $\mathrm{PCO}_{2}$ profiles of the rat inner medullary collecting duct. Am. J. Physiol. 241:F659-F668.

9. Graber, M. L., H. H. Bengele, E. Mroz, C. Lechene, and E. A. Alexander. 1981. Acute metabolic acidosis augments collecting duct acidification rate in the rat. Am. J. Physiol. 241:F669-F676.

10. Ulrich, K. J., and F. Papavassiliou. 1981. Bicarbonate reabsorption in the papillary collecting duct of rats. Pfluegers Arch. Eur. J. Physiol. 389:271-275.

11. Richardson, R. M. A., and R. T. Kunau, Jr. 1982. Bicarbonate reabsorption in the papillary collecting duct: effect of acetazolamide. Am. J. Physiol. 243:F74-F80.

12. Prigent, A., M. Bichara, and M. Paillard. 1985. Hydrogen transport in papillary collecting duct of rabbit kidney. Am. J. Physiol. 248:C241-C246.

13. Grenier, F. C., T. E. Rollins, and W. L. Smith. 1981. Kinin-induced prostaglandin synthesis by renal papillary collecting tubule cells in culture. Am. J. Physiol. 241:F94-F104.

14. Cragoe, E. J., Jr., O. W. Woltersdorf, Jr., J. B. Bicking, S. F. Kwong, and J. H. Jones. 1967. Pyrazine diuretics. II. N-amidino-3amino-5-substituted-6-halopyrazine-carboxamides. J. Med. Chem. 10:66-75.

15. Pearse, A. G. E. 1972. Histochemistry, Theoretical and Applied. Churchill Livingstone, London. 1518 pp.

16. Kriz, W., and B. Kaissling. 1985. Structural organization of the mammalian kidney. In The Kidney: Physiology and Pathophysiology. D. W. Seldin and G. Giebisch, editors. Raven Press, New York. 265-306.

17. Zeidel, M. L., P. Silva, and J. L. Seifter. 1986. Intracellular pH regulation and proton transport by rabbit renal medullary collecting duct cells. J. Clin. Invest. 77:113-120.

18. Lee, J. B., and H. M. Peter. 1969. Effect of oxygen tension on glucose metabolism in rabbit kidney cortex and medulla. Am. J. Physiol. 217:1464-1471.

19. Lehninger, A. L. 1975. Oxidative phosphorylation, mitochondrial structure, and the compartmentation of respiratory metabolism. Biochemistry. Worth Publishers, New York. 19:519-520.

20. Kaunitz, J. D., R. D. Gunther, and G. Sachs. 1985. Characterization of an electrogenic ATP and chloride-dependent proton translocating pump from rat renal medulla. J. Biol. Chem. 260:1156711573.

21. Roos, A., and W. F. Boron. 1981. Intracellular pH. Physiol. Rev. 61:296-434.

22. Rink, T. J., R. Y. Tsien, and T. Pozzan. 1982. Cytoplasmic pH and free $\mathrm{Mg}^{2+}$ in lymphocytes. J. Cell Biol. 95:189-196.

23. Grinstein, S., C. A. Clarke, and A. Rothstein. 1983. Activation of $\mathrm{Na}^{+} / \mathrm{H}^{+}$exchange in lymphocytes by osmotically induced volume changes and by cytoplasmic acidification. J. Gen. Physiol. 82:619-638.

24. Moolenaar, W. H., L. G. J. Tertoolen, and S. W. de Laat. 1984. The regulation of cytoplasmic pH in human fibroblasts. J. Biol. Chem. 259:7563-7569.

25. Farquhar, M. G., and G. E. Palade. 1963. Junctional complexes in various epithelia. J. Cell Biol. 17:375-412.

26. Schwartz, G. J., J. Barasch, and Q. Al-Awqati. 1985. Plasticity of functional epithelial polarity. Nature (Lond.). 318:368-371. 
27. Gluck, S., S. Kelly, and Q. Al-Awqati. 1982. The proton translocating ATPase responsible for urinary acidification. J. Biol. Chem. 257:9230-9233.

28. Lubansky, H. J., and J. A. L. Arruda. 1985. Plasma membrane proton-ATPase of a turtle bladder epithelial cell line. J. Biol. Chem. 260:4035-4040.

29. Stone, D. K., X.-S. Xie, and E. Racker. 1983. An ATP driven proton pump in clathrin-coated vesicles. J. Biol. Chem. 258:40595062.

30. Galloway, C. J., G. E. Dean, M. Marsh, G. Rudnick, and I. Mellman. 1983. Acidification of macrophage and fibroblast endocytic vesicles in vitro. Proc. Natl. Acad. Sci. USA. 80:3334-3338.

31. Glickman, J., K. Croen, S. Kelly, and Q. Al-Awqati. 1983. Golgi membranes contain an electrogenic $\mathrm{H}^{+}$pump in parallel with a chloride conductance. J. Cell Biol. 97:1303-1308.

32. Rees-Jones, R., and Q. Al-Awqati. 1984. Proton-translocating adenosinetriphosphatase in rough and smooth microsomes from rat liver. Biochemistry. 23:2236-2240.

33. Steinmetz, P. R. 1974. Cellular mechanisms of urinary acidification. Physiol. Rev. 54:890-956.

34. Husted, R. F., and P. R. Steinmetz. 1979. The effects of amiloride and ouabain on urinary acidification by turtle bladder. J. Pharmacol. Exp. Ther. 210:264-268.

35. Arruda, J. A. L., G. Dytko, R. Mola, and N. A. Kurtzman 1980. On the mechanism of lithium-induced distal renal tubular acidosis: studies in the turtle bladder. Kidney Int. 17:196-204.

36. Laski, M. E., and N. A. Kurtzman. 1983. Characterization of acidification in the cortical and medullary collecting tubule of the rabbit. J. Clin. Invest. 72:2050-2059.

37. LaBelle, E. F. 1984. Reconstituted amiloride-inhibited sodium transporter from rabbit kidney medulla is responsible for $\mathrm{Na}^{+}-\mathrm{H}^{+}$exchange. Biochim. Biophys. Acta. 770:79-92.

38. Vigne, P., C. Frelin, E. J. Cragoe, Jr., and M. Lazdunski. 1983. Ethylisopropylamiloride: a new and highly potent derivative of amiloride for the inhibition of the $\mathrm{Na}^{+} / \mathrm{H}^{+}$exchange system in various cell types. Biochem. Biophys. Res. Commun. 116:86-90.
39. Vigne, P., C. Frelin, E. J. Cragoe, Jr., and M. Lazdunski. 1984. Structure-activity relationships of amiloride and certain of its analogues in relation to the blockade of the $\mathrm{Na}^{+} / \mathrm{H}^{+}$exchange system. Mol. Pharmacol. 25:131-136.

40. Warnock, D. G., and J. Eveloff. 1982. $\mathrm{NaCl}$ entry mechanisms in the luminal membrane of the renal tubule. Am. J. Physiol. 242:F561-F574.

41. Aronson, P. S. 1983. Mechanisms of active $\mathrm{H}^{+}$secretion in the proximal tubule. Am. J. Physiol. 245:F647-F659.

42. Bichara, M., M. Paillard, F. Leviel, and J.-P. Gardin. 1980. Hydrogen transport in rabbit kidney proximal tubules: $\mathrm{Na}: \mathrm{H}$ exchange. Am. J. Physiol. 238:F445-F451.

43. Blumenthal, S. S., R. A. Ware, and J. G. Kleinman. 1983. Sodium gradient-driven transport processes in ATP-depleted renal tubules. Am. J. Physiol. 244:FC331-C335.

44. Schwartz, G. J. 1981 . $\mathrm{Na}^{+}$-dependent efflux from proximal tubule; evidence for reversible $\mathrm{Na}^{+}-\mathrm{H}^{+}$exchange. Am. J. Physiol. 241:F380-F385.

45. Rindler, M. J., M. Taub, and M. H. Saier, Jr. 1979. Uptake of ${ }^{22} \mathrm{Na}^{+}$by cultured dog kidney cells (MDCK). J. Biol. Chem. 254:11431-11439.

46. Fine, L. G., B. Badie-Dezfooly, A. G. Lowe, A. Hamzeh, J. Wells, and S. Salehmoghaddam. 1985. Simulation of $\mathrm{Na}^{+} / \mathrm{H}^{+}$antiport is an early event in hypertrophy of renal proximal tubular cells. Proc. Natl. Acad. Sci. USA. 82:1736-1740.

47. Pollack, A. S., D. G. Warnock, and G. J. Strewler. 1986. Parathyroid hormone inhibition of $\mathrm{Na}^{+}-\mathrm{H}^{+}$antiporter activity in a cultured renal cell line. Am. J. Physiol. 250:F217-F225.

48. Cantiello, H. F., J. A. Scott, and C. A. Rabito. 1986. Polarized distribution of the $\mathrm{Na}^{+} / \mathrm{H}^{+}$exchange system in a renal cell line (LLC$\mathrm{PK}_{1}$ ) with characteristics of proximal tubular cells. J. Biol. Chem. 261:3242-3258.

49. Laski, M. E. 1987. Total $\mathrm{CO}_{2}$ flux in isolated collecting tubules during carbonic anhydrase inhibition. Am. J. Physiol. 252:F322-F330. 